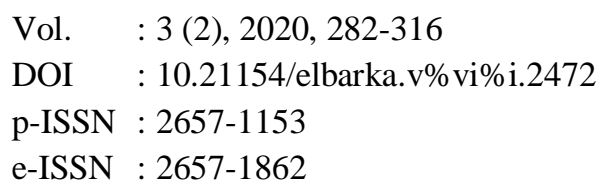

\title{
DAMPAK IMPLEMENTASI RESTRUKTURISASI PEMBIAYAAN TERHADAP LIKUIDITAS BANK SYARIAH PADA SITUASI PANDEMI COVID-19
}

\author{
Abdul Kholiq, Rizqi Rahmawati
}

Institut Agama Islam Negeri Ponorogo, Indonesia

Universitas Merdeka Ponorogo, Indonesia

Email: abdulkholiq1622@gmail.com,rizqi.rahma@gmail.com

\begin{abstract}
The Covid-19 pandemic has had a significant impact in all aspects of human life, such as in the health, education, social, economic and banking sectors. To restore the economic and banking sectors, the government through The Financial Services Authority issued Peraturan Otoritas Jasa Keuangan Republik Indonesia Nomor 11 /POJK.03/2020 Tentang Stimulus Perekonomian Nasional Sebagai Kebijakan Countercyclical Dampak Penyebaran Coronavirus Disease 2019. One of the things described in POJK Number $11 /$ POJK.03/2020 is the implementation of credit or financing restructuring for debtors who were affected during the Covid-19 pandemic. The implementation of this credit / financing restructuring has raised concerns about bank liquidity. This study uses a qualitative descriptive analysis method by describing the phenomena that occur due to the impact of Covid-19 on the global and national economy, Indonesian government policies, and banking. The results showed that during the period March-September 2020 the average Financing to Deposit Ratio (FDR) in Islamic Commercial Banks showed a value of $79.31 \%$ where the highest ratio occurred in July with a ratio level of $81.03 \%$ and the lowest ratio occurred in September with a ratio of $77.06 \%$. Under these conditions, in general the level of liquidity of Islamic commercial banks is categorized as healthy or liquid. The average FDR ratio in Sharia Business Units for the period March-September 2020 shows a value of $103.54 \%$ where the highest ratio occurred in May with an FDR ratio of $107.20 \%$ and the lowest ratio occurred in September with an FDR ratio
\end{abstract}


of $95.87 \%$. Under these conditions, in general the liquidity level of the Sharia Business Unit is categorized as less healthy or less liquid.

Keywords: covid-19, financing restructuring, liquidity risk.

Abstrak: Pandemi Covid-19 telah memberikan dampak yang signifikan dalam segala segi kehidupan manusia seperti dalam bidang kesehatan, pendidikan, sosial, ekonomi maupun sektor perbankan. Untuk memulihkan sektor ekonomi dan perbankan, pemerintah melalui Otoritas Jasa Keuangan mengeluarkan Peraturan Otoritas Jasa Keuangan Republik Indonesia Nomor 11 /POJK.03/2020 Tentang Stimulus Perekonomian Nasional Sebagai Kebijakan Countercyclical Dampak Penyebaran Coronavirus Disease 2019. Salah satu hal yang dijelaskan dalam POJK Nomor 11 /POJK.03/2020 adalah pemberlakuan restrukturisasi kredit atau pembiayaan bagi debitur yang terdampak selama pandemi Covid-19. Pemberlakuan restrukturisasi kredit/pembiayaan ini memunculkan kekhawatiran terhadap likuiditas bank. Penelitian ini bertujuan untuk menganalisa dampak implementasi restrukturisasi pembiayaan terhadap likuiditas bank syariah pada situasi pandemic covid-19. Penelitian ini menggunakan metode analisis deskriptif kualitatif dengan cara mendeskripsikan fenomena-fenomena yang terjadi akibat dampak Covid-19 terhadap perekonomian global maupun nasional, kebijakan pemerintah Indonesia, serta perbankan. Hasil penelitian menunjukkan bahwa selama periode Maret-September 2020 rata-rata rasio Financing to Deposit Ratio (FDR) pada Bank Umum Syariah menunjukkan nilai $79,31 \%$ dimana rasio tertinggi terjadi pada bulan Juli dengan tingkat rasio $81,03 \%$ dan rasio terendah terjadi pada bulan September dengan tingkat rasio 77,06\%. Dengan kondisi tersebut, maka secara umum tingkat likuiditas bank umum syariah dikategorikan sehat atau likuid. Rata-rata rasio FDR pada Unit Usaha Syariah periode Maret-Septemer 2020 menunjukkan nilai 103,54\% dimana rasio tertinggi terjadi pada bulan Mei dengan tingkat rasio FDR $107.20 \%$ dan rasio terendah terjadi pada bulan September dengan tingkat rasio FDR 95.87\%. Dengan kondisi tersebut, maka secara umum tingkat likuiditas Unit Usaha Syariah dikategorikan kurang sehat atau kurang likuid.

Kata Kunci: covid-19, restrukturisasi pembiayaan, risiko likuiditas. 


\section{PENDAHULUAN}

Sebuah wabah baru dilaporkan di Wuhan, Provinsi Hubei, China, pada Desember 2019. Dalam beberapa minggu berikutnya, infeksi menyebar ke seluruh China dan negara lain di seluruh dunia. Pada 30 Januari 2020, World Health Organization (WHO) menyatakan wabah tersebut sebagai Public Health Emergency of International Concern (PHEIC) atau Darurat Kesehatan Global. Pada 12 Februari 2020, WHO menamai wabah tersebut sebagai coronavirus disease 2019 atau COVID-19 (Zu et al, 2020; Sohrabi et al, 2020).

COVID-19 memberikan dampak yang sangat masif dalam segala sendi kehidupan. Dalam bidang pendidikan, COVID-19 telah mengubah model pembelajaran menjadi pembelajaran jarak jauh atau online learning (Crawford et al, 2020; Chick et al, 2020;. Churiyah et al, 2020; Zaharah et al, 2020). Dalam bidang sosial, perkiraan jumlah kehilangan pekerjaan karena COVID-19 diambil dari siaran pers International Labour Organization (ILO) pada 18 Maret 2020, melaporkan penurunan 24,7 juta pekerjaan sebagai skenario tinggi dan 5,3 juta pekerjaan hilang sebagai skenario rendah. Dalam skenario tinggi, tingkat pengangguran di seluruh dunia akan meningkat dari 4,936\% menjadi 5,644\%, yang akan dikaitkan dengan peningkatan kasus bunuh diri sekitar 9570 per tahun. Dalam skenario rendah, pengangguran akan meningkat menjadi $5,088 \%$, dengan peningkatan kasus bunuh diri sekitar 2135 kasus per tahun (Kawohl \& Nordt, 2020).

Dalam bidang sosial khususnya di negara Indonesia, COVID19 juga diperkirakan akan berdampak pada tingkat kemiskinan dimana dalam skenario terbaik, tingkat kemiskinan akan naik dari 9,2\% di 
September 2019 menjadi 9,7\% pada akhir 2020, mendorong 1,3 juta tambahan orang ke dalam kemiskinan. Pada skenario terburuk, tingkat kemiskinan akan naik menjadi 16,6\%, mendekati level pada 2004 ketika kemiskinan mencapai $16,7 \%$. Artinya, akan ada pertambahan 19,7 juta orang miskin, dan dengan demikian secara substansial membalikkan kemajuan yang telah dicapai Indonesia dalam mengurangi angka kemiskinan (Suryahadi et al, 2020).

Dalam bidang ekonomi, guncangan ekonomi global akibat dari COVID-19 lebih cepat dan lebih parah daripada krisis keuangan global 2008. Data menunjukan bahwa pasar saham ambruk hingga 50\% bahkan lebih, pasar kredit membeku, diikuti kebangkrutan besarbesaran, tingkat pengangguran melonjak di atas 10\% dan Produk Domestik Bruto (PDB) menyusut pada tingkat tahunan 10\% bahkan lebih (Abodunrin, et al, 2020). Pasar saham global kehilangan kekayaan sekitar US \$ 6 triliun dalam satu minggu dari tanggal 24 hingga 28 Februari 2020. Indeks S\&P 500 kehilangan nilai lebih dari \$ 5 triliun pada minggu yang sama sementara 10 perusahaan terbesar S\&P 500 mengalami kerugian gabungan lebih dari \$ 1,4 triliun (Ozili and Arun, 2020). Penetrasi COVID-19 terhadap pasar modal memberikan dampak cukup serius. Selain mempengaruhi tingkat keputusan investasi dari beberapa investor sehingga terlihat begitu signifikan dampaknya, COVID-19 juga membuat kondisi mental investor menjadi panik dan membuat pasar saham global mendapat tekanan hebat (Burhanuddin \& Abdi, 2020).

Khusus pada sektor perbankan, adanya physical distancing menyebabkan sektor usaha tidak berjalan, sehingga sektor usaha yang memiliki pinjaman di bank mengalami kesulitan dalam pembayaran. 
Apabila hal itu dibiarkan, maka akan berpengaruh pada tingkat kolekbilitas kredit. Sedangkan tingkat kesehatan bank sangat dipengaruhi oleh nilai kredit macet sebuah bank. Kredit bermasalah akan membawa bank menghadapi resiko kredit akibat ketidakmampuan debitur dalam membayar kredit (Bidari \& Nurviana, 2020).

Kredit maupun pembiayaan yang bermasalah atau non performing financing (NPF) akan berdampak pada return on asset (ROA) atau profitabilitas bank (Putrianingsih \& Yulianto, 2016; Rizal, 2016; Rizal \& Rofiqo, 2020). Menurut Yusuf et al (2019) hasil korelasi antara non performing financing (NPF) dan return on asset (ROA) pada bank umum syariah yang terdaftar di Otoritas Jasa Keuangan (OJK) terdapat hubungan yang kuat dan negatif, artinya semakin tinggi NPF maka akan menurunkan ROA. Semakin tinggi nilai NPF akan berdampak pada penurunan profitabilitas bank. Tingginya nilai NPF juga berdampak pada kesehatan bank. Semakin besar NPF maka semakin besar pula kerugian yang dialami bank yang kemudian akan mengakibatkan berkurangnya keuntungan bank. Keuntungan yang berkurang akan mengakibatkan total aset bank tersebut juga ikut berkurang (Almunawaroh \& Marliana, 2018; Agustin \& Darmawan, 2018). Berbeda dengan penelitian sebelumnya, beberapa penelitian menyatakan bahwa pembiayaan bermasalah tidak berpengaruh pada tingkat profitabilitas bank. Hal ini dimungkinkan karena NPF bank kecil sehingga tidak dapat mempengaruhi ROA (Mahmudah \& Harjanti, 2016; Simatupang \& Franzlay, 2016). 
Untuk menilai Non Performing Financing pada Bank Syariah menggunakan Matriks Kriteria Penetapan Peringkat Profil Risiko sebagai berikut:

Tabel.1. Matriks Kriteria Penetapan Peringkat Profil Risiko (NPF)

\begin{tabular}{ccc}
\hline Peringkat & Keterangan & Kriteria NPF \\
\hline 1 & Sangat Memadai & $\mathrm{NPF}<2 \%$ \\
2 & Memadai & $2 \% \leq \mathrm{NPF}<5 \%$ \\
3 & Cukup Memadai & $5 \% \leq \mathrm{NPF}<8 \%$ \\
4 & Kurang Memadai & $8 \% \leq \mathrm{NPF}<12 \%$ \\
5 & Tidak Memadai & $\mathrm{NPF} \geq 12 \%$ \\
\hline
\end{tabular}

Sumber: Kodifikasi Peraturan Bank Indonesia Kelembagaan Penilaian Tingkat Kesehatan Bank

Respons pemerintah sebagai upaya mengatasi krisis keuangan tersebut dengan mengeluarkan regulasi atas pengaturan keuangan negara. Ada dua regulasi keuangan negara yang dikeluarkan untuk mengatur pembiayaan keuangan bagi masyarakat. Dua aturan tersebut yaitu Peraturan Pemerintah Pengganti Undang-Undang (Perppu) Nomor 1 Tahun 2020 dan Peraturan Otoritas Jasa Keuangan (POJK) Nomor 11/POJK.03/2020. Perppu Nomor 1 Tahun 2020 pada tanggal 18 Mei 2020 telah meningkat status hukumnya menjadi UndangUndang Nomor 2 Tahun 2020. Kedua aturan tersebut menjadi payung hukum pemberlakuan restrukturisasi kredit atau pembiayaan bagi debitur yang terdampak pandemi COVID-19 (Ubaidillah \& Aji, 2020). Kebijakan stimulus ini berlaku dengan jangka waktu satu tahun setelah penetapan, dengan mekanisme diserahkan kepada kondisi setiap lembaga keuangan dan kemampuan pembayaran debitur. Sehingga dalam praktek penerapan kebijakan ini bisa sangat beragam dari 
lembaga keuangan yang satu dengan yang lain (Bidari \& Nurviana, 2020).

Secara lebih detail Peraturan Otoritas Jasa Keuangan Republik Indonesia Nomor 11 /POJK.03/2020 mengandung pokok-pokok pengaturan sebagai berikut:

1. POJK ini berlaku bagi Bank Umum Konvensional, Bank Umum Syariah, Unit Usaha Syariah, Bank Perkreditan Rakyat, dan Bank Pembiayaan Rakyat Syariah.

2. Bank dapat menerapkan kebijakan yang mendukung stimulus pertumbuhan ekonomi untuk debitur yang terkena dampak penyebaran COVID-19 termasuk debitur UMKM, dengan tetap memperhatikan prinsip kehati-hatian.

3. Debitur yang terkena dampak penyebaran COVID-19 termasuk debitur UMKM adalah debitur yang mengalami kesulitan untuk memenuhi kewajiban pada Bank karena debitur atau usaha debitur terdampak dari penyebaran COVID-19 baik secara langsung ataupun tidak langsung pada sektor ekonomi antara lain pariwisata, transportasi, perhotelan, perdagangan, pengolahan, pertanian, dan pertambangan.

4. Kebijakan stimulus dimaksud terdiri dari: (1) Penilaian kualitas kredit/pembiayaan/penyediaan dana lain hanya berdasarkan ketepatan pembayaran pokok dan/atau bunga untuk kredit/pembiayaan/penyediaan dana lain dengan plafon s.d Rp10 miliar. (2) Peningkatan kualitas kredit/pembiayaan menjadi lancar setelah direstrukturisasi selama masa berlakunya POJK. Ketentuan restrukturisasi ini dapat diterapkan Bank tanpa melihat batasan plafon kredit/pembiayaan atau jenis debitur. 
5. Cara restrukturisasi kredit/pembiayaan dilakukan sebagaimana diatur dalam peraturan OJK mengenai penilaian kualitas aset, antara lain dengan cara: penurunan suku bunga; perpanjangan jangka waktu; pengurangan tunggakan pokok; pengurangan tunggakan bunga; penambahan fasilitas kredit/pembiayaan; dan/atau konversi kredit/pembiayaan menjadi Penyertaan Modal Sementara.

6. Bank dapat memberikan kredit/pembiayaan/penyediaan dana lain yang baru kepada debitur yang telah memperoleh perlakuan khusus sesuai POJK ini dengan penetapan kualitas kredit/pembiayaan/penyediaan dana lain tersebut dilakukan secara terpisah dengan kualitas kredit/pembiayaan/penyediaan dana lain sebelumnya.

7. Bank menyampaikan laporan berkala atas penerapan POJK ini untuk monitoring Pengawas sejak posisi data akhir bulan April 2020.

8. Ketentuan ini berlaku sejak diundangkan sampai dengan tanggal 31 Maret 2021.

Pada tanggal 23 Oktober 2020, Otoritas Jasa Keuangan (OJK) melalui siaran pers OJK SP 72/DHMS/OJK/X/2020 menegaskan memperpanjang kebijakan restrukturisasi kredit/pembiayaan selama setahun. Hal ini setelah memperhatikan asesmen terakhir OJK terkait debitur restrukturisasi sejak diputuskannya rencana memperpanjang relaksasi ini pada saat Rapat Dewan Komisioner OJK. Perpanjangan restrukturisasi ini sebagai langkah antisipasi untuk menyangga terjadinya penurunan kualitas debitur restrukturisasi. Namun kebijakan perpanjangan restrukturisasi diberikan secara selektif berdasarkan 
asesmen bank untuk menghindari moral hazard agar debitur tetap mau dan mampu melakukan kegiatan ekonomi dengan beradaptasi ditengah masa pandemi. OJK segera memfinalisasi kebijakan perpanjangan restrukturisasi ini dalam bentuk Peraturan Otoritas Jasa Keuangan (POJK) termasuk memperpanjang beberapa stimulus lanjutan yang terkait antara lain pengecualian perhitungan aset berkualitas rendah (loan at risk) dalam penilaian tingkat kesehatan bank, governance persetujuan kredit restrukturisasi, penyesuaian pemenuhan capital conservation buffer dan penilaian kualitas Agunan yang Diambil Alih (AYDA) serta penundaan implementasi Basel III.

\section{Direktur riset Center of Reform on Economics (CORE)} Indonesia Piter Abdullah mengatakan dengan restrukturisasi, setidaknya bank terjaga dari tekanan rasio kredit bermasalah dan tidak ada kewajiban membentuk Pencadangan Penghapusan Aktiva Produktif (PPAP) sehingga akan membuat likuiditas perbankan terjaga. Namun, bukan berarti dengan restrukturisasi semua permasalahan selesai. Pasalnya, tekanan likuiditas bisa datang dari hal lainnya, seperti dari berkurangnya aliran uang masuk, pertumbuhan dana pihak ketiga (DPK) yang menurun dan penarikan DPK yang meningkat (Finansial.Bisnis.com, 2020).

Sementara itu Gita Wirjawan selaku Wakil Ketua Dewan Pertimbangan Kamar Dagang dan Industri (Kadin) memproyeksikan kebutuhan dana restukturisasi bakal mencapai sekitar Rp3000 triliun atau $45 \%$ dari total kredit perbankan. Gita pun mengingatkan, program restrukturisasi kredit menjadi penting untuk menjaga keberlangsungan perekonomian nasional di tengah pandemi COVID-19. Pasalnya, kredit juga dianggap sebagai sisi pasok yang sangat dibutuhkan saat ini 
bagi banyak pelaku usaha. Jika nilai kredit yang mesti direstrukturisasi sangat besar, sudah pasti akan berdampak serius buat kreditur dalam hal ini perbankan. Menurut Sunarso selaku Direktur Utama Bank Rakyat Indonesia (BRI), restrukturisasi kredit ini akan mempengaruhi bank dari sisi likuiditas dan juga income (pendapatan). Likuiditas bank akan terganggu, karena nasabah yang kreditnya direrstrukturisasi mendapat penundaan pembayaran pokok hutangnya (Ekbis.Sindonews.com, 2020)

POJK 11/POJK.03/2020 ditujukan untuk mendorong kinerja perbankan khususnya fungsi intermediasi, menjaga stabilitas sistem keuangan, dan mendukung pertumbuhan ekonomi yaitu dengan memberikan perlakuan khusus terhadap kredit atau pembiayaan Bank kepada debitur yang terkena dampak penyebaran coronavirus disease 2019 (COVID-19) termasuk debitur usaha mikro, kecil, dan menengah. Di sisi lain, kebijakan ini juga berpotensi mengganggu likuiditas dan pendapatan perbankan. Berangkat dari penjabaran di atas penelitian ini bertujuan untuk menganalisa dampak implementasi restrukturisasi pembiayaan terhadap likuiditas bank syariah pada situasi pandemic COVID-19.

\section{TINJAUAN LITERATUR}

\section{Coronavirus Disease 2019 (COVID-19)}

Pada awal Desember 2019, kasus pneumonia pertama yang tidak diketahui asalnya diidentifikasi di Wuhan, ibu kota provinsi Hubei, China. Patogen tersebut telah diidentifikasi sebagai virus RNA betacoronavirus baru yang saat ini dinamai sindrom pernapasan akut coronavirus 2 (SARS-CoV-2) yang memiliki kemiripan filogenetik 
dengan SARS-CoV (Guan et al, 2020). Coronavirus terbungkus virus RNA sense positif dengan diameter mulai dari $60 \mathrm{~nm}$ hingga $140 \mathrm{~nm}$ dengan proyeksi seperti lonjakan di permukaannya sehingga membuatnya tampak seperti mahkota di bawah mikroskop elektron yang karenanya dinamai virus corona. Empat virus corona sebelumnya yakni HKU1, NL63, 229E dan OC43 telah beredar di manusia, dan umumnya menyebabkan penyakit saluran pernapasan ringan (Singhal, 2020).

Gejala infeksi COVID-19 muncul setelah masa inkubasi kurang lebih 5 hari (Lauer et al, 2020; Rothan \& Byrareddy, 2020). Periode dari timbulnya gejala COVID-19 hingga kematian berkisar antara 6 hingga 41 hari dengan median 14 hari. Periode ini tergantung pada usia pasien dan status sistem imun pasien. Gejala paling umum saat timbulnya penyakit COVID-19 adalah demam, batuk, dan kelelahan, sedangkan gejala lainnya meliputi produksi sputum, sakit kepala, hemoptisis, diare, dispnea, dan limfopenia (Rothan \& Byrareddy, 2020).

Saat ini, belum ada vaksin dan pengobatan khusus untuk COVID-19. Strategi terbaik untuk menangani epidemi SARS-CoV-2 adalah dengan mengendalikan sumber infeksi, melindungi orang yang rentan, dan memutus penularan. Pasien yang terinfeksi harus diidentifikasi lebih awal dengan teknologi deteksi yang cepat dan akurat serta dilakukan perawatan yang optimal dalam ruang yang terisolasi. Orang-orang yang berhubungan dekat dengan pasien yang terinfeksi harus dikarantina. Orang yang sehat harus waspada dan mengambil tindakan untuk melindungi diri mereka sendiri, seperti tinggal di rumah, membatasi kontak sosial, dan mengenakan masker 
pelindung di depan umum. Pihak berwenang harus mendorong orang untuk tinggal di rumah, mencegah berkumpulnya massa, menunda atau membatalkan acara publik, dan menutup lembaga publik. Tindakan pengendalian ini akan membantu negara yang terinfeksi COVID-19 untuk mencegah epidemi secara efektif (He et al, 2020).

Pemerintah mengeluarkan kebijakan untuk meminimalkan dampak COVID-19 di sektor perbankan dengan mengeluarkan POJK No.11 /POJK.03/2020. Salah satu kebijakan tersebut mengatur mengenai restrukturisasi pembiayaan. Restrukturisasi bukanlah penghapusan, tetapi memberikan kelonggaran untuk melunasi pembayaran utang. Pinjaman masih harus dibayar tetapi diberikan keringanan berdasarkan penilaian dan kesepakatan dengan Bank (Ningsih \& Mahfudz, 2020).

\section{Restrukturisasi Pembiayaan}

Dalam hal terdapat pembiayaan bermasalah, upaya penyelesaian yang dapat dilakukan pihak bank dapat berupa rescheduling, reconditioning, restructuring, penyelesaian melalui jaminan serta hapus buku dan atau hapus tagih (Turmudi, 2016). Penyelesaian serupa juga disarankan oleh Wahyuni dan Werastuti dalam Ibrahim dan Rahmati (2017) yaitu melalui tindakan penyelamatan berupa restrukturisasi pembiayaan dalam rangka membantu nasabah untuk menyelesaikan kewajibannya, melalui: 1) penjadwalan kembali (rescheduling), 2) persyaratan kembali (reconditioning), dan 3) penataan kembali (restructuring).

Menurut pasal 1 ayat 7 Peraturan Bank Indonesia (PBI) No. 18/PBI/2008 yang dimaksud dengan restrukturisasi pembiayaan adalah 
upaya yang dilakukan Bank dalam rangka membantu nasabah agar dapat menyelesaikan kewajibannya, antara lain melalui:

1. Penjadwalan kembali (rescheduling), yaitu perubahan jadwal pembayaran kewajiban nasabah atau jangka waktunya.

2. Persyaratan kembali (reconditioning), yaitu perubahan sebagian atau seluruh persyaratan pembiayaan, antara lain perubahan jadwal pembayaran, jumlah angsuran, jangka waktu dan/atau pemberian potongan sepanjang tidak menambah sisa kewajiban nasabah yang harus dibayarkan kepada Bank.

3. Penataan kembali (restructuring), yaitu perubahan persyaratan pembiayaan tidak terbatas pada rescheduling atau reconditioning, antara lain meliputi: penambahan dana fasilitas pembiayaan bank; konversi akad pembiayaan; konversi pembiayaan menjadi surat berharga syariah berjangka waktu menengah; konversi pembiayaan menjadi penyertaan modal sementara pada perusahaan nasabah.

Teknis pelaksanaan restrukturisasi pembiayaan pada pasal 5 PBI No. 10/18/PBI/2008 dijelaskan bahwa restrukturisasi pembiayaan hanya dapat dilakukan untuk nasabah dengan kriteria: (1) nasabah mengalami penurunan kemampuan pembayaran. (2) nasabah memiliki prospek usaha yang baik dan mampu memenuhi kewajiban setelah restrukturisasi. Restrukturisasi pembiayaan hanya dapat dilakukan untuk pembiayaan dengan kualitas kurang lancar, diragukan dan macet. Selanjutnya restrukturisasi pembiayaan wajib didukung dengan analisis dan bukti-bukti yang memadai serta terdokumentasi dengan baik. 
Aturan teknis pelaksanaan restrukturisasi pembiayaan ini diperbarui dengan Peraturan Bank Indonesia Nomor: 13/9/PBI/2011. Pada pasal 5 dijelaskan bahwa restrukturisasi pembiayaan hanya dapat dilakukan untuk nasabah yang memenuhi kriteria sebagai berikut: (1) nasabah mengalami penurunan kemampuan pembayaran. (2) nasabah memiliki prospek usaha yang baik dan mampu memenuhi kewajiban setelah restrukturisasi. Sedangkan restrukturisasi untuk pembiayaan konsumtif hanya dapat dilakukan untuk nasabah yang memenuhi kriteria sebagai berikut: (1) nasabah mengalami penurunan kemampuan pembayaran. (2) terdapat sumber pembayaran angsuran yang jelas dari nasabah dan mampu memenuhi kewajiban setelah restrukturisasi. Selain itu, restrukturisasi pembiayaan wajib didukung dengan analisis dan bukti-bukti yang memadai serta didokumentasikan dengan baik

Pelaksanaan restrukturisasi pembiayaan pada bank harus tetap memenuhi prinsip syariah disamping mengacu kepada prinsip kehatihatian yang bersifat universal yang berlaku pada industri perbankan. Selain itu, aspek kebutuhan dan kesesuaian dengan perkembangan industri perbankan syariah menjadi pertimbangan dalam penyempurnaan ketentuan mengenai Restrukturisasi Pembiayaan di Bank Syariah dan Unit Usaha Syariah (Kolistiawan, 2014).

\section{Risiko Likuiditas}

Risiko likuiditas adalah risiko yang disebabkan oleh ketidakmampuan bank memenuhi kewajiban yang telah jatuh tempo. LDR (Loan to Deposit Ratio) adalah indikator yang digunakan untuk risiko likuiditas. LDR menggambarkan kemampuan bank membayar 
kembali penarikan yang dilakukan deposan dengan mengandalkan kredit yang diberikan sebagai sumber likuiditas. LDR dirumuskan dengan membandingkan jumlah kredit yang disalurkan dengan dana pihak ketiga (Capriani \& Dana, 2016). Dalam perbankan syariah tidak ada istilah kredit (loan), yang ada dalam perbankan syariah adalah pembiayaan (financing) sehingga LDR dalam bank syariah disebut sebagai Financing to Deposit Ratio (FDR) (Simatupang \& Franzlay, 2016)

FDR merupakan perbandingan antara pembiayaan yang diberikan oleh bank dengan dana pihak ketiga yang berhasil dikerahkan oleh bank. Maksimal FDR yang diperkenankan oleh Bank Indonesia adalah sebesar $110 \%$. Rasio ini menyatakan seberapa jauh kemampuan bank dalam membayar kembali penarikan dana yang dilakukan deposan dengan mengandalkan kredit atau pembiayaan yang diberikan sebagai likuiditasnya (Suhartatik \& Kusumaningtias, 2013).

Sebagaimana yang dijelaskan pada pasal 1 ayat 9 Peraturan Bank Indonesia Nomor 13/23/PBI/2011 yang dimaksud dengan risiko likuiditas adalah risiko akibat ketidakmampuan bank untuk memenuhi kewajiban yang jatuh tempo dari sumber pendanaan arus kas dan/atau aset likuid berkualitas tinggi yang dapat diagunkan, tanpa mengganggu aktivitas dan kondisi keuangan bank. Bank dapat dikatakan likuid apabila bank memiliki sejumlah likuiditas dan/atau memegang alat-alat likuid, cash assets (uang kas, rekening pada bank sentral dan bank lainnya) sama dengan jumlah kebutuhan likuiditas yang diperkirakan, memiliki likuiditas kurang dari kebutuhan, dan memiliki kemampuan untuk memperoleh likuiditas dengan cara menciptakan uang. Sebagai lembaga kepercayaan bagi masyarakat maka bank harus bisa 
mengelola likuiditas secara baik terutama ditunjukan untuk memperkecil risiko likuiditas yang disebabkan oleh adanya kekurangan, dalam mengelola likuiditas selalu akan terjadi benturan kepentingan antara keputusan untuk menjaga likuiditas dan meningkatkan pendapatan (Bani \& Yaya, 2018).

Menurut Chen et al (2018) risiko likuiditas biasanya diukur dengan rasio likuiditas, yang secara operasional didefinisikan dalam dua arah yang berbeda. Jenis definisi pertama menganggap aset likuiditas yang disesuaikan dengan ukuran sebagai ukuran rasio likuiditas, termasuk rasio aset likuid terhadap total aset, rasio aset likuid terhadap simpanan dan aset likuid terhadap nasabah serta pendanaan jangka pendek. Jenis definisi kedua mempertimbangkan pinjaman yang disesuaikan dengan ukuran, seperti rasio pinjaman terhadap total aset dan pinjaman bersih terhadap pelanggan dan rasio pendanaan jangka pendek. Pada kelompok pertama, nilai rasio likuiditas yang lebih tinggi menunjukkan lebih banyak likuiditas dan oleh karena itu tidak terlalu rentan terhadap kegagalan. Sebaliknya, pada kelompok kedua, semakin tinggi nilai rasio tersebut maka bank akan mengalami risiko likuiditas yang semakin besar dan rentan terhadap kegagalan.

Penilaian aspek likuiditas menunjukkan kemampuan bank untuk mengelola tingkat likuiditas yang memadai dalam rangka memenuhi kewajibannya secara tepat waktu dan untuk memenuhi kebutuhan yang lain. Bank juga harus dapat mengelola kegiatannya secara efisien dalam arti bahwa bank dapat menekan biaya pengelolaan likuiditas yang tinggi serta setiap saat bank dapat melikuidasi asetnya secara cepat dengan kerugian yang minimal. Ketidakmampuan bank 
dalam memenuhi kebutuhan likuiditasnya bisa berdampak pada timbulnya kerugian atau kebangkrutan perbankan. Karena itu, manajemen risiko likuiditas menjadi penting untuk menjaga kelangsungan hidup perbankan (Nugraheni \& Alam, 2014).

Penilaian faktor likuiditas digunakan untuk mengukur kemampuan bank dalam memenuhi kewajiban jangka pendek. Dalam penelitian ini, rasio yang digunakan untuk menilai faktor likuiditas adalah Rasio Financing to Deposits Ratio (FDR).

Tabel 2. Matriks Kriteria Penetapan Peringkat Profil Risiko (FDR)

\section{Peringkat}

\begin{tabular}{ccc}
\hline 1 & Sangat Memadai & $50 \% \leq \mathrm{FDR}<75 \%$ \\
2 & Sehat & $75 \% \leq \mathrm{FDR}<85 \%$ \\
3 & Cukup Memadai & $85 \% \leq \mathrm{FDR}<100 \%$ \\
4 & Kurang Memadai & $100 \% \leq \mathrm{FDR}<120 \%$ \\
5 & Tidak Memadai & FDR $\geq 120 \%$ \\
\hline
\end{tabular}

Sumber: Kodifikasi Peraturan Bank Indonesia Kelembagaan Penilaian Tingkat Kesehatan Bank

\section{METODE PENELITIAN}

Penelitian ini bertujuan untuk menganalisa dampak implementasi restrukturisasi pembiayaan terhadap likuiditas bank syariah pada situasi pandemi COVID-19. Metode penelitian yang digunakan dalam penelitian ini adalah dengan menggunakan analisis deskriptif kualitatif. Dengan cara mendeskripsikan fenomenafenomena yang terjadi akibat dampak virus corona (COVID-19) terhadap perekonomian global, kebijakan pemerintah Indonesia, serta sektor perbankan. Teknik pengumpulan data pada penelitian ini melalui studi pustaka (library research) yaitu teknik pengumpulan data dari berbagai bahan pustaka (referensi) yang relevan dan mempelajari 
masalah yang akan dibahas. Studi pustaka merupakan metode pengumpulan data yang diarahkan kepada pencarian data dan informasi melalui dokumen-dokumen seperti dokumen tertulis, fotofoto, gambar, maupun dokumen elektronik yang dapat mendukung dalam proses penulisan.

\section{HASIL DAN PEMBAHASAN}

Coronavirus disease 19 (COVID-19) merupakan virus yang menginfeksi saluran pernafasan pada tubuh manusia. infeksi ditandai dengan adanya gejala paling umum seperti demam, batuk, dan kelelahan. Virus ini telah memberikan dampak yang besar pada segala sektor seperti pendidikan, sosial, ekonomi dan juga perbankan, baik konvensional maupun perbankan syariah.

Berdasarkan kajian yang dibuat oleh Kementerian Keuangan menunjukkan bahwa pandemi COVID-19 memberikan implikasi negatif bagi perekonomian domestik seperti penurunan konsumsi dan daya beli masyarakat, penurunan kinerja perusahaan, ancaman pada sektor perbankan dan keuangan, serta eksistensi UMKM. Kebijakan social distancing yang kemudian diubah menjadi physical distancing dan bekerja dari atau di rumah berdampak pada penurunan kinerja perusahaan yang kemudian diikuti oleh pemutusan hubungan kerja. Bahkan ada beberapa perusahaan yang mengalami kebangkrutan dan akhirnya memilih untuk menutup usahanya. Pada aspek perbankan dan keuangan, pandemi ini memunculkan ketakutan akan terjadinya masalah pembayaran hutang atau kredit yang pada akhirnya berdampak pada keberlangsungan kinerja bank. Banyak kreditur yang 
sudah meminta kelonggaran batas dan besaran pembayaran cicilan hutang dan kredit kepada bank (Pakpahan, 2020).

Perbankan Syariah merupakan bank yang melaksanakan kegiatan usahanya berdasarkan prinsip syariah. Bank syariah pada awalnya dikembangkan sebagai salah satu respon dari kelompok ekonom dan praktisi perbankan muslim yang berupaya mengakomodasi desakan dari berbagai pihak yang menginginkan agar tersedia jasa transaksi keuangan yang dilaksanakan sejalan dengan nilai moral dan prinsi-prinsip syariah Islam. Berikut disajikan data perkembangan aset, pembiayaan yang disalurkan (PYD) dan dana pihak ketiga (DPK) bank syariah di Indonesia per Juni 2020.

Tabel 3. Perkembangan Aset, Pembiayaan yang disalurkan (PYD) dan Dana Pihak Ketiga (DPK) (Dalam Triliun Rp)

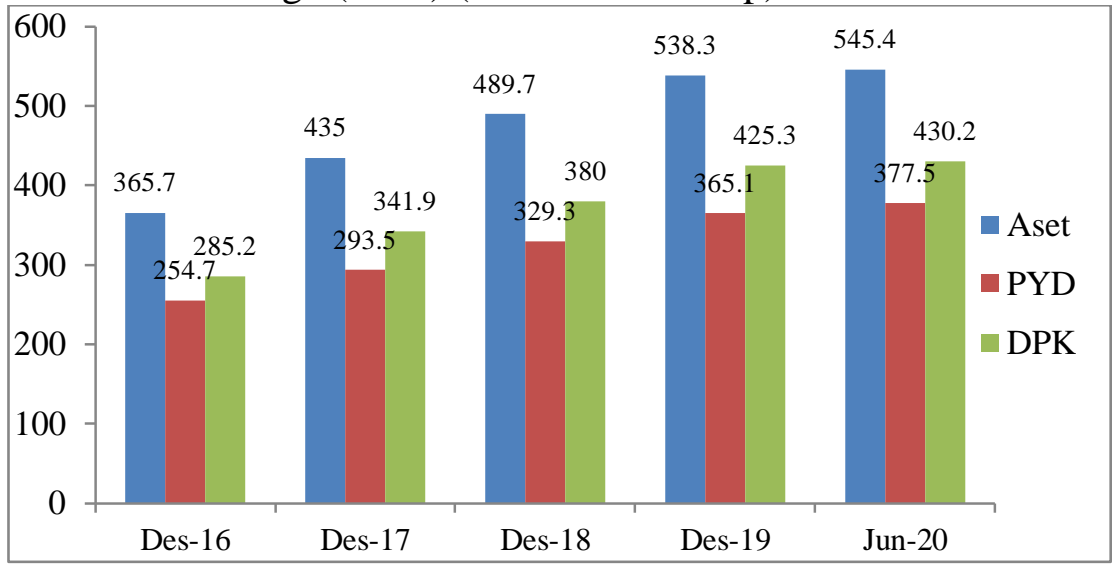

Sumber: Snapshot Perbankan Syariah Indonesia Juni 2020

Berdasarkan data pada tabel di atas terlihat perkembangan bank syariah dilihat dari Aset, Pembiayaan yang disalurkan (PYD) dan Dana pihak ketiga (DPK) yang cukup positif. Terdapat lonjakan nilai yang begitu signifikan dalam waktu kurang dari 4 tahun. Dari sisi aset, terjadi kenaikan sebesar 179,7 Triliun atau sebesar 49,12\%, dimana pada periode desember 2016 total aset perbankan syariah di Indonesia 
adalah 365,7 triliun menjadi 545,4 triliun pada Juni 2020. Dari sisi pembiayaan yang disalurkan (PYD), terjadi kenaikan sebesar 122,8 triliun atau sebesar 48,21\%, dimana pada periode desember 2016 total pembiayaan yang disalurkan oleh perbankan syariah adalah 254,7 triliun menjadi 377,5 triliun pada Juni 2020. Dari sisi dana pihak ketiga (DPK), terjadi kenaikan sebesar 145 triliun atau sebesar 50,84\%, dimana pada periode Desember 2016 total dana pihak ketiga yang dapat dihimpun oleh perbankan syariah sebesar 285,2 triliun menjadi 430,2 triliun pada Juni 2020.

Perkembangan perbankan syariah sejalan dengan keinginan nasabah muslim yang menginginkan adanya layanan jasa perbankan yang sesuai dengan syariat Islam. Perbankan mempunyai fungsi sebagai lembaga intermediasi, yaitu sebagai penghimpun dan penyalur dana. Bank syariah akan menginvestasikan dana yang dihimpun dari masyarakat pada dunia usaha, dengan menggunakan alat-alat investasi yang sesuai dengan syariah Islam. Dalam menjalanan fungsi ini bank syariah hanya bertindak sebagai perantara antara pihak yang memerlukan dana dan yang ingin menginvestasikan dananya dengan pihak yang memerlukan dana.

Pembiayaan merupakan salah satu bentuk penyaluran dana ke pihak yang memerlukan/membutuhkan. Berdasarkan data Otoritas Jasa Keuangan (OJK) dalam Snapshot Perbankan Syariah Indonesia Juni 2020 sampai dengan Juni 2020 jumlah pembiayaan yang disalurkan oleh bank syariah sebesar 377,53 Triliun dengan jumlah rekening sebanyak 5,68 juta. Dari jumlah tersebut, pembiayaan yang digunakan untuk konsumsi sebesar 45,02\%, modal kerja sebesar 31,60\% dan investasi sebesar $23,38 \%$ dengan 5 sektor terbesar pembiayaan yang 
disalurkan adalah rumah tangga $(39,07 \%)$, perdagangan besar dan eceran $(10,28 \%)$, konstruksi $(8,98 \%)$, industri pengolahan $(7,37 \%)$, perantara keuangan (4,92\%). Sebelum terjadi penyebaran COVID-19 di Indonesia, perbankan syariah diharapkan akan tumbuh terus mencapai pertumbuhan double digit, namun akibat pandemi ini bank syariah harus merubah rencana bisnisnya di tahun 2020 .

Upaya pemerintah dalam menekan penyebaran virus COVID19 dimulai setelah munculnya virus di Indonesia yaitu dengan melakukan himbauan untuk tidak melakukan aktivitas di luar rumah. Caranya dengan memberlakukan sosial distancing dan Pembatasan Sosial Bersekala Besar (PSBB), namun dengan adanya kebijakan tersebut memunculkan permasalahan baru yang dirasakan oleh seluruh kalangan. Kebijakan sosial distancing dan Pembatasan Sosial Bersekala Besar (PSBB) berdampak pada sektor ekonomi di Negara Indonesia dimana laju pertumbuhan ekonomi mengalami pelambatan. dan sektor perbankan menjadi sektor yang cukup terdampak dari pelambatan laju pertumbuhan ekonomi tersebut.

Pemerintah melalui Otoritas Jasa Keuangan (OJK) mengeluarkan Peraturan No. 11/POJK.03/2020 yang ditujukan sebagai pendorong kinerja perbankan khususnya fungsi intermediasi, menjaga stabilitas sistem keuangan, dan mendukung pertumbuhan ekonomi. Bank dapat menerapkan kebijakan yang mendukung stimulus pertumbuhan ekonomi terhadap debitur yang terdampak penyebaran COVID-19 termasuk debitur usaha mikro, kecil dan menengah (UMKM) melalui restrukturisasi kredit maupun pembiayaan. Dengan berlakunya restrukturisasi tersebut ternyata mempunyai dampak resiko 
terhadap sektor perbankan mulai dari risiko kredit/pembiayaan, risiko pasar, risiko operasional, dan risiko likuiditas.

- Likuiditas pada umumnya adalah mengenai posisi uang kas suatu perusahaan dan kemampuan untuk memenuhi kewajiban (membayar utang) yang jatuh tempo tepat pada waktunya. Apabila dikaitkan dengan lembaga perbankan, bisa diartikan kemampuan bank seriap waktu untuk membayar utang jangka pendeknya apabila tibatiba ditagih oleh nasabah atau pihak-pihak terkait. Penyediaan likuiditas yang cukup merupakan salah satu hal terpenting dalam setiap sistem keuangan, dengan hal ini perantara keuangan selalu berusaha mengelola posisi likuiditas.dan Bank merupakan lembaga yang sangat merencanakan posisi likuiditas dengan sangat hati-hati karena akan sangat berpengaruh pada kepercayaan nasabah. Risiko likuditas dapat melekat pada aktivitas fungsional perkreditan/pembiayaan, dalam hal ini karena adanya pandemi COVID-19 membuat perekonomian melemah sehingga berpengaruh terhadap kemampuan debitur untuk membayar pokok dan/atau angsuran dan bunga atau margin/bagi hasil/ujrah. Tertundanya pembayaran jelas mempengaruhi likuiditas bank, seperti tercermin dari data di bawah ini.

Tabel 4. Rasio Keuangan Bank Umum Syariah (BUS) dan Unit Usaha Syariah (UUS)

\begin{tabular}{lcccccccc}
\hline \multicolumn{2}{l}{ Indikator } & \multicolumn{7}{c}{$\mathbf{2 0 2 0}$} \\
\cline { 2 - 9 } & & Mar & Apr & Mei & Jun & Jul & Ags & Sept \\
\hline $\begin{array}{l}\text { NPF } \\
(\%)\end{array}$ & BUS & 3.43 & 3.41 & 3.35 & 3.34 & 3.31 & 3.30 & 3.28 \\
& UUS & 3.05 & 3.08 & 3.24 & 3.42 & 3.38 & 3.33 & 3.17 \\
$\begin{array}{l}\text { FDR } \\
(\%)\end{array}$ & BUS & 78.93 & 78.69 & 80.50 & 79.37 & 81.03 & 79.56 & 77.06 \\
& UUS & 106.52 & 105.06 & 107.20 & 104.86 & 104.41 & 100.89 & 95.87 \\
\hline
\end{tabular}

Sumber: Statistik Perbankan Syariah September 2020 
Data di atas menyajikan statistik perbankan syariah sejak diberlakukannya Peraturan Otoritas Jasa Keuangan Republik Indonesia Nomor 11 /POJK.03/2020 Tentang Stimulus Perekonomian Nasional Sebagai Kebijakan Countercyclical Dampak Penyebaran Coronavirus Disease 2019 mulai dari Maret 2020 sampai dengan September 2020.

Non Performing Financing (NPF) merupakan pembiayaan macet yang berpengaruh terhadap laba bank syariah. NPF erat kaitannya dengan pembiayaan yang disalurkan oleh bank syariah kepada nasabahnya. NPF yang mencerminkan resiko pembiayaan Bank Umum Syariah Selama periode Maret-September 2020 mengalami fluktuatif. Rata-rata rasio NPF menunjukkan nilai 3,35\% dengan rasio NPF tertinggi adalah pada bulan Maret sebesar 3,43\% dan rasio NPF terendah adalah pada bulan September sebesar 3,28\%. Jika ditinjau menggunakan Matriks Kriteria Penetapan Peringkat Profil Risiko yang diukur dengan rasio NPF, maka secara keseluruhan Bank Umum Syariah berada pada peringkat 2 dengan kriteria NPF berada pada rentang $2 \% \leq \mathrm{NPF}<5 \%$. Dengan kondisi tersebut maka tingkat profil risiko yang diukur dengan rasio NPF pada Bank Umum syariah dikategorikan memadai yang artinya kualitas penerapan manajemen resiko pembiayaan juga dikategorikan memadai. Meskipun terdapat beberapa kelemahan minor, tetapi kelemahan terebut dapat diselesaikan pada aktivitas bisnis normal.

Sementara itu pada Unit Usaha Syariah, rata-rata rasio NPF selama periode Maret-September 2020 menunjukkan nilai 3,24\% dengan rasio NPF tertinggi terjadi pada bulan Juni sebesar 3,42\% dan rasio NPF terendah terjadi pada bulan Maret sebesar 3,05\%. Jika ditinjau menggunakan Matriks Kriteria Penetapan Peringkat Profil 
Risiko yang diukur dengan rasio NPF, maka secara keseluruhan Unit Usaha Syariah berada pada peringkat 2 dengan kriteria NPF berada pada rentang $2 \% \leq \mathrm{NPF}<5 \%$. Dengan kondisi tersebut maka tingkat profil risiko yang diukur dengan rasio NPF pada Unit Usaha Syariah dikategorikan memadai yang artinya kualitas penerapan manajemen resiko pembiayaan juga dikategorikan memadai. Meskipun terdapat beberapa kelemahan minor, tetapi kelemahan tersebut dapat diselesaikan pada aktivitas bisnis normal.

Berlakunya kebijakan social distancing dan pemberhentian sementara kegiatan ekonomi memiliki dampak pada tingginya rasio NPF pada bulan Maret 2020 sebesar 3,43\%. Namun setelah pemerintah mengeluarkan kebijakan baru sebagai stimulus untuk mendorong perekonomian dengan membuka aktiftas ekonomi seperti sebelumnya, rasio NPF mulai bergerak turun pada bulan Mei sebesar 3,35\%. Dan pada bulan September rasio NPF mencapai titik terendahnya sebesar 3,28\%. Akan tetapi hal yang berbeda justru terjadi pada Unit Usaha Syariah dimana pada bulan Maret 2020 merupakan titik terendah rasio NPF yaitu sebesar 3,05\%. Kemudian rasio NPF bergerak naik hingga mencapai titik tertinggi pada bulan Juni 2020 sebesar 3,42\% hingga kembali bergerak turun yang pada bulan September mencapai 3,17\%.

Penurunan rasio NPF artinya tingkat permasalahan pembiayaan yang dihadapi Bank Umum Syariah maupun Unit Usaha Syariah semakin menurun sehingga kualitas pembiayaan Bank Umum Syariah maupun Unit Usaha Syariah lebih baik dari sebelumnya. Sebaliknya, Peningkatan rasio NPF artinya tingkat permasalahan pembiayaan yang dihadapi Bank Umum Syariah maupun Unit Usaha Syariah semakin 
meningkat sehingga kualitas pembiayaan Bank Umum Syariah maupun Unit Usaha Syariah lebih buruk dari sebelumnya

Financing to Deposit Ratio (FDR) adalah perbandingan antara pembiayaan yang diberikan oleh bank dengan dana pihak ketiga yang berhasil dihimpun oleh bank. Semakin tinggi rasio ini, maka semakin rendah pula kemampuan likuiditas bank tersebut. Selama periode Maret-September 2020 rasio FDR pada Bank Umum Syariah berada pada kisaran $77 \%$ - $81 \%$ dengan rata-rata rasio FDR selama periode bulan tersebut menunjukkan nilai 79,31\% dimana rasio tertinggi terjadi pada bulan Juli dengan tingkat rasio $81,03 \%$ dan rasio terendah terjadi pada bulan September dengan tingkat rasio $77,06 \%$. Jika ditinjau menggunakan Matriks Kriteria Penetapan Peringkat Profil Risiko (FDR), maka pada periode Maret 2020 hingga September 2020 Bank Umum Syariah secara keseluruhan berada pada peringkat 2 dengan kriteria FDR berada pada $75 \% \leq$ FDR $<85 \%$. Dengan kondisi tersebut, maka secara umum tingkat likuiditas bank umum syariah dikatakan sehat atau likuid yang artinya kemampuan likuiditas bank untuk mengantisipasi kebutuhan likuiditas dan penerapan manajemen risiko likuiditas kuat.

Selanjutnya rasio FDR pada Unit Usaha Syariah periode Maret-Septemer 2020 berada pada kisaran 95\% - 107\% dengan ratarata rasio FDR menunjukkan nilai $103,54 \%$ dimana rasio tertinggi terjadi pada bulan Mei dengan tingkat rasio FDR $107.20 \%$ dan rasio terendah terjadi pada bulan September dengan tingkat rasio FDR 95.87\%. Jika ditinjau menggunakan Matriks Kriteria Penetapan Peringkat Profil Risiko (FDR), maka pada periode Maret 2020 hingga Agustus 2020 Unit Usaha Syariah secara keseluruhan berada pada 
peringkat 4 dengan kriteria FDR berada pada 100\% $\leq$ FDR $<120 \%$. Dengan kondisi tersebut, maka secara umum tingkat likuiditas Unit Usaha Syariah dikatakan kurang sehat atau kurang likuid yang artinya kemampuan likuiditas unit usaha syariah untuk mengantisipasi kebutuhan likuiditas dan penerapan manajemen risiko likuiditas lemah. Tingginya tingkat Financing to Deposit Ratio (FDR) tersebut karena pembiayaan yang disalurkan selama bulan Maret - Agustus 2020 lebih besar daripada Dana Pihak ketiga (DPK). Namun kondisi ini membaik di bulan September 2020 dimana dengan tingkat rasio FDR 95.87\%. maka secara umum Unit Usaha Syariah berada pada peringkat 3 dengan kriteria FDR berada pada 85\% $\leq$ FDR $<100 \%$. Dengan kondisi tersebut, maka secara umum tingkat likuiditas Unit Usaha Syariah dinilai cukup sehat yang artinya kemampuan likuiditas bank untuk mengantisipasi kebutuhan likuiditas dan penerapan manajemen risiko likuiditas memadai.

Meskipun secara keseluruhan Bank Umum Syariah dinilai cukup sehat, namun jika dilihat secara rasio selama periode Mei, Juni, Juli dan Agustus terjadi peningkatan rasio FDR yang nilainya di atas rata-rata rasio FDR periode Maret-September 2020. Hal ini menunjukkan bahwa peningkatan rasio FDR mengindikasikan kemampuan Bank Umum Syariah dalam memenuhi kewajiban jangka pendeknya pada saat ditagih semakin rendah atau dengan kata lain tingkat likuiditas bank umum syariah semakin menurun. Sebaliknya Unit Usaha Syariah Secara keseluruhan dinilai kurang sehat, jika dilihat secara rasio selama periode Mei, Juni, Juli dan Agustus. Selama priode tersebut, terjadi peningkatan rasio FDR yang nilainya diatas nilai rata-rata rasio FDR periode Maret-September 2020. Hal ini 
menunjukkan bahwa peningkatan rasio FDR mengindikasikan kemampuan Unit Usaha Syariah dalam memenuhi kewajiban jangka pendeknya pada saat ditagih semakin rendah atau dengan kata lain tingkat likuiditas Unit Usaha Syariah semakin menurun.

Dikutip dari media online Keuangan.Kontan.Co.Id (2020) Otoritas Jasa Keuangan selama pandemi COVID-19 selalu memantau likuiditas setiap bank, jika mengalami permasalahan atau dikatakan spare likuditas menipis maka bank akan didorong untuk memakai intercall money Call money merupakan sumber dana yang dapat diperoleh bank berupa pinjaman jangka pendek dari bank lain melalui interbank call money market. Sumber dana ini sering digunakan oleh bank untuk memenuhi kebutuhan dana mendesak dalam jangka pendek, seperti bila terjadi kalah kliring atau adanya rush. Apabila Iikuiditas perbankan secara umum di suatu area sedang sulit, tingkat bunga call money bisa menjadi sangat tinggi, jauh lebih tinggi daripada tingkat bunga pinjaman umum. Call money dapat juga dimanfaatkan oleh bank yang sedang mengalami kelebihan likuiditas untuk menyalurkan dananya dalam jangka pendek, sehingga kelebihan likuiditas tersebut menjadi dana yang produktif menghasilkan penerimaan bagi bank (Sari, 2016).

Menjaga likuditas selain dengan menggunakan intercall money, perbankan syariah dapat melakukan pinjaman likuiditas ke BI (Bank Indonesia) sesuai Peraturan Pemerintah Pengganti Undang-Undang Republik Indonesia Nomor 1 Tahun 2020. Pada pasal 16 ayat $1 \mathrm{~b}$ dijelaskan bahwa Bank Indonesia diberikan wewenang untuk memberikan pinjaman likuiditas khusus kepada bank sistemik yang mengalami kesulitan likuiditas dan tidak memenuhi persyaratan 
pemberian pinjaman likuiditas jangka pendek atau pembiayaan likuiditas jangka pendek berdasarkan prinsip syariah yang dijamin oleh Pemerintah dan diberikan berdasarkan Keputusan Komite Stabilitas Sistem Keuangan (KSSK).

\section{KESIMPULAN}

Pandemi coronavirus disease 2019 (COVID-19) telah memberikan dampak negatif terhadap perekonomian Indonesia. Pandemi menimbulkan adanya ketidakpastian yang berkepanjangan sehingga investasi ikut melemah dan berimplikasi pada terhentinya usaha. Sektor UMKM mengalami dampak cukup dalam akibat pandemi Covid-19. Perilaku ini disebabkan adanya penurunan jumlah pembeli dan berubahnya frekuensi belanja masyarakat. UMKM pun terpukul, mulai dari penjualan dan pendapatan merosot hingga kesulitan dalam produksi. Kredit/pembiayaan yang berjalan pun menjadi tersendat sehingga mengalami kesulitan pembayaran. Pandemi COVID-19 juga berdampak signifikan pada sektor perbankan. Penyaluran kredit/pembiayaan menjadi salah satu core bisnis perbankan sedikit terhambat karena ketidakpastian dan anjloknya aktivitas ekonomi yang berdampak pada perputaran uang.

Untuk menanggulangi dampak yang ditimbulkan pandemi COVID-19 ini pemerintah meresponnya dengan berbagai kebijakan, salah satunya adalah dikeluarkannya Peraturan Otoritas Jasa Keuangan Republik Indonesia Nomor 11 /POJK.03/2020 Tentang Stimulus Perekonomian Nasional Sebagai Kebijakan Countercyclical Dampak Penyebaran Coronavirus Disease 2019 yang memuat restrukturisasi 
kredit/pembiayaan. Pemberlakuan restrukturisasi kredit/pembiayaan ini memunculkan kekhawatiran terhadap likuiditas bank.

Financing to Deposit Ratio (FDR) digunakan untuk menilai likuiditas bank. Selama periode Maret-September 2020 rasio FDR pada Bank Umum Syariah rata-rata rasio FDR menunjukkan nilai $79,31 \%$ dimana rasio tertinggi terjadi pada bulan Juli dengan tingkat rasio $81,03 \%$ dan rasio terendah terjadi pada bulan September dengan tingkat rasio $77,06 \%$. Dengan kondisi tersebut, maka secara umum tingkat likuiditas bank umum syariah dikatakan sehat atau likuid yang artinya kemampuan likuiditas bank untuk mengantisipasi kebutuhan likuiditas dan penerapan manajemen risiko likuiditas kuat. Sedangkan rasio FDR pada Unit Usaha Syariah periode Maret-Septemer 2020 berada pada kisaran 95\% - 107\% dengan rata-rata rasio FDR menunjukkan nilai $103,54 \%$ dimana rasio tertinggi terjadi pada bulan Mei dengan tingkat rasio FDR $107.20 \%$ dan rasio terendah terjadi pada bulan September dengan tingkat rasio FDR 95.87\%. Dengan kondisi tersebut, maka secara umum tingkat likuiditas Unit Usaha Syariah dikatakan kurang sehat atau kurang likuid yang artinya kemampuan likuiditas unit usaha syariah untuk mengantisipasi kebutuhan likuiditas dan penerapan manajemen risiko likuiditas lemah. Tingginya tingkat Financing to Deposit Ratio (FDR) tersebut karena pembiayaan yang disalurkan selama bulan Maret-Agustus 2020 lebih besar daripada Dana Pihak ketiga (DPK). Namun kondisi ini membaik di bulan September 2020 dimana dengan tingkat rasio FDR 95.87\%. Dengan kondisi tersebut, maka secara umum tingkat likuiditas Unit Usaha Syariah dinilai cukup sehat yang artinya kemampuan likuiditas bank 
untuk mengantisipasi kebutuhan likuiditas dan penerapan manajemen risiko likuiditas memadai.

\section{REFERENSI}

Abodunrin, O., Oloye, G., \& Adesola, B. (2020). Coronavirus Pandemic and Its Implication on Global Economy. International Journal of Arts, Languages and Business Studies, 4. 13-23.

Agustin, P. T., \& Darmawan, A. (2018). Pengaruh Rasio Keuangan Terhadap Kinerja Keuangan Bank Syariah (Studi pada Bank Umum Syariah yang Terdaftar di Otoritas Jasa Keuangan Republik Indonesia Tahun 2014-2016). Jurnal Administrasi Bisnis, 64(1), 102-108.

Almunawwaroh, M., \& Marliana, R. (2018). Pengaruh CAR, NPF dan FDR Terhadap Profitabilitas Bank Syariah di Indonesia. Amwaluna: Jurnal Ekonomi dan Keuangan Syariah, 2(1), 1-17.

Bani, F., \& Yaya, R. (2018). Risiko Likuiditas pada Perbankan Konvensional dan Syariah di Indonesia. Jurnal Riset Akuntansi dan Bisnis, 16(1). 1-26.

Bank Indonesia. (2008). Peraturan Bank Indonesia Nomor: 10/18/PBI/2008 Tentang Restrukturisasi Pembiayaan bagi Bank Syariah dan Unit Usaha Syariah.

Bank Indonesia. (2011). Peraturan Bank Indonesia Nomor 13/23/PBI/2011 Tentang Penerapan Manajemen Risiko Bagi Bank Umum Syariah dan Unit Usaha Syariah.

Bank Indonesia. (2011). Peraturan Bank Indonesia Nomor: 13/9/PBI/2011 Tentang Perubahan atas Peraturan Bank Indonesia Nomor 10/18/PBI/2008 Tentang Restrukturisasi Pembiayaan Bagi Bank Syariah dan Unit Usaha Syariah.

Bank Indonesia. (2012). Kodifikasi Peraturan Bank Indonesia Kelembagaan Penilaian Tingkat Kesehatan Bank.

Bidari, A. S., \& Nurviana, R. (2020). Stimulus Ekonomi Sektor Perbankan dalam Menghadapi Pandemi Coronavirus Disease 
2019 di Indonesia. Legal Standing: Jurnal Ilmu Hukum, 4(1), 297-305.

Burhanuddin, C. I., \& Abdi, M. N. (2020). Krisis Ekonomi Global dari Dampak Penyebaran Virus Corona (Covid-19). AkMen Jurnal Ilmiah, 17(1), 90-98.

Capriani, N. W. W., \& Dana, I. M. (2016). Pengaruh Risiko Kredit Risiko Operasional dan Risiko Likuiditas Terhadap Profitabilitas BPR di Kota Denpasar. E-Jurnal Manajemen Universitas Udayana, 5(3). 1486-1512.

Chen, Y. K., Shen, C. H., Kao, L., \& Yeh, C. Y. (2018). Bank liquidity risk and performance. Review of Pacific Basin Financial Markets and Policies, 21(01), 1850007. 1-40.

Chick, R. C., Clifton, G. T., Peace, K. M., Propper, B. W., Hale, D. F., Alseidi, A. A., \& Vreeland, T. J. (2020). Using Technology to Maintain The Education of Residents During The COVID-19 Pandemic. Journal of Surgical Education. 729-732.

Churiyah, M., Sholikhan, S., Filianti, F., \& Sakdiyyah, D. A. (2020). Indonesia Education Readiness Conducting Distance Learning in Covid-19 Pandemic Situation. International Journal of Multicultural and Multireligious Understanding, 7(6), 491-507.

Crawford, J., Butler-Henderson, K., Rudolph, J., Malkawi, B., Glowatz, M., Burton, R., ... \& Lam, S. (2020). COVID-19: 20 Countries' Higher Education Intra-Period Digital Pedagogy Responses. Journal of Applied Learning \& Teaching, 3(1), 1-20.

Ekbis. Sindonews.Com. (2020). Hati-Hati, Restrukturisasi Kredit Bisa Ganggu Likuiditas Perbankan.

Finansial. Bisnis.Com. (2020). Ada Restrukturisasi Kredit, Likuditas Masih jadi Tantangan Bank.

Guan, W. J., Ni, Z. Y., Hu, Y., Liang, W. H., Ou, C. Q., He, J. X., \& Du, B. (2020). Clinical Characteristics of Coronavirus Disease 2019 in China. New England journal of Medicine, 382(18), 1708-1720.

He, F., Deng, Y., \& Li, W. (2020). Coronavirus Disease 2019: What We Know?. Journal of Medical Virology, 92(7), 719-725. 
Ibrahim, A., \& Rahmati, A. (2017). Analisis Solutif Penyelesaian Pembiayaan Bermasalah di Bank Syariah: Kajian Pada Produk Murabahah di Bank Muamalat Indonesia Banda Aceh. Iqtishadia: Jurnal Kajian Ekonomi dan Bisnis Islam STAIN Kudus, 10(1), 71-96.

Kawohl, W., \& Nordt, C. (2020). COVID-19, Unemployment, and Suicide. The Lancet Psychiatry, 7(5), 389-390.

Keuangan. Kontan.Co.Id. (2020). Beban Restrukturisasi Kredit Bisa Menekan Likuiditas Perbankan.

Kolistiawan, B. (2014). Tinjauan Syariah Tentang Pembiayaan Bermasalah di Perbankan Syariah. IAIN Tulungagung Research Collections, 1(1), 185-208.

Lauer, S. A., Grantz, K. H., Bi, Q., Jones, F. K., Zheng, Q., Meredith, H. R., \& Lessler, J. (2020). The Incubation Period of Coronavirus Disease 2019 (Covid-19) From Publicly Reported Confirmed Cases: Estimation and Application. Annals of Internal Medicine, 172(9), 577-582.

Mahmudah, N., \& Harjanti, R. S. (2016). Analisis Capital Adequacy Ratio, Financing to Deposit Ratio, Non Performing Financing, dan Dana Pihak Ketiga Terhadap Tingkat Profitabilitas Bank Umum Syariah Periode 2011-2013. In Prosiding Seminar Nasional IPTEK Terapan (SENIT) 2016 Pengembangan Sumber Daya Lokal Berbasis IPTEK (Vol. 1, No. 1).

Ningsih, M. R., \& Mahfudz, M. S. (2020). Dampak Pandemi Covid-19 Terhadap Manajemen Industri Perbankan Syariah: Analisis Komparatif. Point, 2(1). 1-10.

Nugraheni, P., \& Alam, W. F. I. (2014). Pengaruh Risiko Likuiditas Terhadap Profitabilitas Pada Perbankan Syariah dan Konvensional di Indonesia. Journal of Accounting and Investment, 15(1), 1-16.

Otoritas Jasa Keuangan. (2020). Peraturan Otoritas Jasa Keuangan Republik Indonesia Nomor 11 /POJK.03/2020 Tentang Stimulus Perekonomian Nasional Sebagai Kebijakan Countercyclical Dampak Penyebaran Coronavirus Disease 2019.

Otoritas Jasa Keuangan. (2020). Snapshot Perbankan Syariah Indonesia Juni 2020. 
Otoritas Jasa Keuangan. (2020). SP 72/DHMS/OJK/X/2020 Siaran Pers OJK Perpanjang Relaksasi Restrukturisasi Kredit Selama Setahun.

Otoritas Jasa Keuangan. (2020). Statistik Perbankan Syariah September 2020.

Ozili, P. K., \& Arun, T. (2020). Spillover of COVID-19: Impact on The Global Economy. Available at SSRN 3562570. 1-27

Pakpahan, A. K. (2020). Covid-19 Dan Implikasi Bagi Usaha Mikro, Kecil, dan Menengah. Jurnal Ilmiah Hubungan Internasional, 59-64.

Pemerintah Republik Indonesia. (2020). Peraturan Pemerintah Pengganti Undang-Undang Republik Indonesia Nomor 1 Tahun 2020 Tentang Kebijakan Keuangan Negara dan Stabilitas Sistem Keuangan Untuk Penanganan Pandemi Coronavirus Disease 2019 (Covid-19) dan/atau dalam Rangka Menghadapi Ancaman Yang Membahayakan Perekonomian Nasional dan/atau Stabilitas Sistem Keuangan.

Putrianingsih, D. I., \& Yulianto, A. (2016). Pengaruh Non Performing Loan (NPL) dan Capital Adequacy Ratio (CAR) terhadap Profitabilitas (Studi Kasus pada Perusahaan Perbankan yang Terdaftar di BEI Periode 2010-2013). Management Analysis Journal, 5(2).

Rizal, F. (2016). Pengaruh Capital Adequacy Ratio, Non Performing Finance Dan Operational Efficiency Ratio Terhadap Profitabilitas Bank Pembiayaan Rakyat Syariah. Muslim Heritage, 1(1), 179-196.

Rizal, F., \& Rofiqo, A. (2020). Determinants of Sharia Banking Profitability: Empirical Studies in Indonesia 2011-2020. ElBarka: Journal of Islamic Economics and Business, 3(1), 137161.

Rothan, H. A., \& Byrareddy, S. N. (2020). The Epidemiology and Pathogenesis of Coronavirus Disease (COVID-19) Outbreak. Journal of Autoimmunity, 102433. 1-4.

Sari, N. (2016). Manajemen Dana Bank Syariah. Jurnal Ilmu Syariah: Al-Maslahah, 12(1), 45-61. 
Simatupang, A., \& Franzlay, D. (2016). Capital Adequacy Ratio (CAR), Non Performing Financing (NPF), Efisiensi Operasional (BOPO) dan Financing to Deposit Ratio (FDR) Terhadap Profitabilitas Bank Umum Syariah di Indonesia. Jurnal Administrasi Kantor, 4(2), 466-485.

Singhal, T. (2020). A Review of Coronavirus Disease-2019 (COVID19). The Indian Journal of Pediatrics, 1-6.

Sohrabi, C., Alsafi, Z., O’Neill, N., Khan, M., Kerwan, A., Al-Jabir, A., \& Agha, R. (2020). World Health Organization Declares Global Emergency: A Review of The 2019 Novel Coronavirus (COVID-19). International Journal of Surgery. 71-76.

Suhartatik, N., \& Kusumaningtias, R. (2013). Determinan Financing to Deposit Ratio Perbankan Syariah di Indonesia (20082012). Jurnal Ilmu Manajemen (JIM), 1(4).

Suryahadi, A., Al Izzati, R., \& Suryadarma, D. (2020). Estimating The Impact of Covid-19 on Poverty In Indonesia. Bulletin of Indonesian Economic Studies, 56(2), 175-192.

Turmudi, M. (2016). Manajemen Penyelesaian Pembiayaan Bermasalah Pada Lembaga Perbankan Syariah. Li Falah: Jurnal Studi Ekonomi dan Bisnis Islam, 1(1), 95-106.

Ubaidillah, M., \& Aji, R. H. S. (2020). Tinjauan Atas Implementasi Perpanjangan Masa Angsuran Untuk Pembiayaan di Bank Syariah Pada Situasi Pandemi COVID-19. Islamic Banking: Jurnal Pemikiran Dan Pengembangan Perbankan Syariah, 6(1), $1-16$.

Yusuf, D., Hamdani \& Kholik, K. (2019). The Effect of Buy and Sell Financing (Murabahah), Profit Share Financing (Mudarabah), Equity Capital Financing (Musyarakah) and Non-Performing Financing Ratio on Profitability Level of Sharia Commercial Banks in North Sumatera. Britain International of Humanities and Social Sciences (BIoHS) Journal, 1(1), 81-88.

Zaharah, Z., Kirilova, G. I., \& Windarti, A. (2020). Impact of Corona Virus Outbreak Towards Teaching and Learning Activities in Indonesia. SALAM: Jurnal Sosial dan Budaya Syar-i, 7(3), 269282. 
Abdul Kholiq, Rizqi Rahmawati

Zu, Z. Y., Jiang, M. D., Xu, P. P., Chen, W., Ni, Q. Q., Lu, G. M., \& Zhang, L. J. (2020). Coronavirus Disease 2019 (COVID-19): A Perspective From China. Radiology, 200490. E15-E25 